\title{
Local Entrepreneurship in the Context of Food Production: A Review
}

\author{
Izabela Kwil $^{1}\left[\right.$, Katarzyna Piwowar-Sulej ${ }^{1}$ (1) and Małgorzata Krzywonos ${ }^{2, *(1)}$ \\ 1 Department of Labor and Capital, Wroclaw University of Economics and Business, Komandorska 118/120, \\ 53-345 Wrocław, Poland; izabela.kwil@ue.wroc.pl (I.K.); katarzyna.piwowar-sulej@ue.wroc.pl (K.P.-S.) \\ 2 Department of Bioprocess Engineering, Wroclaw University of Economics and Business, Komandorska \\ 118/120, 53-345 Wrocław, Poland \\ * Correspondence: malgorzata.krzywonos@ue.wroc.pl
}

Received: 13 November 2019; Accepted: 25 December 2019; Published: 6 January 2020

check for updates

\begin{abstract}
Local food production is meaningful not only for a single producer but also for the consumer, and finally for the entire region. Therefore, it would be beneficial to take up the issue of local entrepreneurship in the context of food production. The aim of the study was to analyze important terms, research topics, and research results related to the issue of local entrepreneurship in the context of food production. Literature review revealed definitional discrepancies related to the subject of the study. Thus, the need to create an unambiguous definition of local food and local entrepreneurship was emphasized. Own definitions of these issues were provided. Most of the available publications are devoted to local food produced in selected countries. In the analyzed research papers, the problem of local food is most often correlated with marketing or health-promoting properties of local food. A research gap was identified: suggestions were made in regards to the research problems worth bringing up in empirical research in the interest of activating local entrepreneurship.
\end{abstract}

Keywords: local food; local entrepreneurship; regional products; traditional product; empirical research

\section{Introduction}

In recent years, agricultural companies have been forced to adapt to new challenges such as market changes, changes in consumer habits, food safety, sustainability, and biotechnology [1]. According to the statement by Migliore et al. rapid changes in the agro-food sector (globalization and industrialization) have encouraged agribusiness companies to implement strategies for coping with the economic situation, which are mainly oriented towards mass production and profit maximization. This has raised several environmental concerns related to the exploitation of natural resources and the exclusion of many small family businesses (local producers) in rural areas oriented towards high-quality production from the global market [2]. The specific economic characteristics of the agricultural sector such as strong regulatory environment, mature markets, and start-up subsidies make this sector interesting to study, especially in the context of configuration and restructuring of entrepreneurs' resources [3-6].

Local food production is a subject that is becoming more and more popular in the media because it is associated with high quality ingredients. However, local food is not often known regionally or nationally. Moreover, the term "local food" is defined in various ways. For example, Coelho et al. [7] define it as food produced in close proximity to where the consumers live. However, these authors also point out that alternative food or culturally significant food is sometimes treated as local food. What is more, local food is often equated to such terms as 'traditional food' or 'regional food'. The latter term, though, has specific labeling. 
It is important for particular regions to produce products which are not only healthy and tasty, but also well known. Factors that play an important role in regional promotion are culture, history, and the skills that people have as well as the local land. Local food production is inherently connected with the local entrepreneur.

The term 'entrepreneurship' was coined at the turn of the 19th century. The First Industrial Revolution can be pinpointed as the beginning of the scientific and research interest in entrepreneurship. At that time, entrepreneurship was associated with creating new forms of administration and economization of social life. It manifested itself in an appropriate use of capital, technology, raw materials, and human potential. Allocation of capital was incidental to risk related to the opportunity to quickly multiply profits or possibility to suffer a financial loss or go bankrupt. The term entrepreneurship was explained in works of representatives of economic and social liberal thought. Smith, Say, and Schumpeter are considered to be the precursors.

As pointed out by Hjorth and Steyaert [8], there is very little agreement on the issue of entrepreneurship. The terms entrepreneurship and entrepreneur were first described in the 18th century in a study written by Say. He presented entrepreneur as a person who allocates his own capital to risky and unknown investment. An analysis of literature on the subject of management shows that Drucker was first to present the definition of entrepreneurship. He specified that entrepreneurship is related to the introduction of new, better changes which are meant to build a foundation for the future business activity, without overlooking the optimum way to use the already owned resources [9]. Entrepreneurship can also be understood as an attitude or process of entrepreneurial changes resulting from this attitude. Such entrepreneurship manifests itself in readiness to take on new or improve the already existing activities. In his pursuit of reaching intended financial gains, the entrepreneur intends to increase his profits as well as improve his work and life conditions [10]. Griffin [11] on the other hand, pointed out that entrepreneurship is a process of organizing and running a business activity as well as taking risks related to running such activity. He was first to specify the semantic scope of the term entrepreneur.

Modern definitions emphasize that the "process of designing, launching and running a new business is often related to a small business" [12]. A model of entrepreneurship created by Morris, Lewis, and Sexton [13] includes:

- 'input' element encompassing important factors of entrepreneurship (opportunities, existence of an entrepreneur, organizational conditions),

- entrepreneurial process encompassing identification of opportunities, preparation and clarification of the concept, acquisition of resources, and implementation,

- 'output' element encompassing functioning of the venture, creation of values, new products and services, financial effect (including gain or loss, employment, assets).

Many typologies of entrepreneurship can be found in literature. What is surprising, is that these typologies do not adopt any particular criterion of division [14]. Several types of entrepreneurship can be distinguished including spontaneous, evolutionary, academic, technology, innovative, family, social, ecological, and female. Even though the general definition of entrepreneurship mentions building a new business, there is a separate type of entrepreneurship-corporate entrepreneurship (or intraentrepreneurship), which refers to entrepreneurial activities-such as innovation, venturing, and strategic renewal—within existing firms [15].

One can also come across a general definition of local entrepreneurship which describes entrepreneurship as a new and complex value creation on a local market that triggers change-examples would be a new production structure, new product, or new premises-and affects other firms, actors, and economic players in this locality. The new value disturbs the market in some way, causing the locality itself to change and ultimately develop by responding better to the needs of its own citizens and outside customers, and by creating more inside jobs and wealth, leading ultimately to local economic development [16]. 
Taking the above into consideration we have formulated the following research objectives:

1. Conducting an analysis of terms such as 'local food', 'regional food', and 'traditional food'. Formulating, on the basis of this analysis, an unambiguous definition of local food and local entrepreneurship related strictly to the production of analyzed food.

2. Conducting an analysis of the research topics and research results related to the issue of local entrepreneurship in the context of food production, identifying the research gap and research problems worth taking up in empirical research in the interest of activating local entrepreneurship.

\section{Materials and Methods}

Literature study conducted for the purpose of this paper included materials from the electronic database of publications-Web of Science (WoS) uploaded before 15.05.2019. This database was selected because-similarly to the Scopus database-it lists most of the international literature from a variety of scientific disciplines. There are many papers which are indexed in both of the above-mentioned databases.

An assumption was made in regards to the search, namely that the search will be based on the titles of publications because the keywords that are the main focus of the study are usually used in the title. An analysis of the contents of all publications (articles, book chapters, proceedings papers) which came up as a result of the search using queries: 'local food', 'local food', and 'entrepreneurship', as well as 'local food' and 'producer' was conducted. The Scopus search engine showed 1399 publications in total while WoS showed 1169. However, WoS includes more open access publications, 333, while Scopus includes 229.

The first publication which included searched words in the title was published in 2005. As a result, publications which were published since that point in time were accepted for analysis (Table 1).

Table 1. Number of publications devoted to the analyzed topic indexed in WoS and published in years 2005-2018.

\begin{tabular}{|c|c|c|c|c|c|c|c|c|c|c|c|c|c|c|c|}
\hline $\begin{array}{c}\text { Year } \\
\text { of Publication }\end{array}$ & 苂 & ఫั่ & કેे & 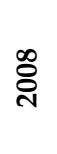 & ஓें & 올 & ت्ञ & ํํำ & 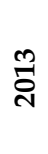 & ت্்ّ & 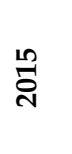 & : & 令 & $\stackrel{\infty}{\stackrel{\sim}{*}}$ & 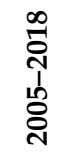 \\
\hline $\begin{array}{l}\text { Publications including } \\
\text { "local food" }\end{array}$ & 17 & 37 & 23 & 33 & 38 & 70 & 67 & 69 & 98 & 86 & 156 & 145 & 167 & 149 & 1155 \\
\hline $\begin{array}{l}\text { Publications including "local } \\
\text { food + entrepreneurship" }\end{array}$ & 1 & 0 & 0 & 0 & 0 & 0 & 0 & 0 & 0 & 0 & 0 & 1 & 1 & 1 & 4 \\
\hline $\begin{array}{l}\text { Publications including "local } \\
\text { food + producer" }\end{array}$ & 1 & 1 & 0 & 0 & 0 & 0 & 0 & 0 & 0 & 1 & 2 & 1 & 3 & 1 & 10 \\
\hline Total & 19 & 38 & 23 & 33 & 38 & 70 & 67 & 69 & 98 & 87 & 158 & 147 & 171 & 151 & 1169 \\
\hline
\end{tabular}

Having prepared the statistics of publications the authors read the abstracts of all the articles which were displayed by search engines. Even if the content of the abstract was determined to be irrelevant, we analyzed the content of the paper in order to present, e.g., different ways of defining the issue of 'being local'.

In their analysis the authors chose two perspectives, i.e., topic of research and its relation to the particular geographical area. The process of analysis took 5 months.

It is not possible to present a summary of all the articles within this paper. Therefore, the authors illustrated the research topics by means of a presentation of several publications from each of the research areas. 


\section{Results of Literature Studies}

\subsection{Regional Products, Traditional Product, Local Product-Definitional Issues}

Making a distinction between terms regional or traditional and local product is very difficult because they are often used interchangeably. Such situation may lead to mistakes in the analysis of production statistics as well as reasons for customers' and producers' behaviors. What is interesting is that after typing the phrase 'local food' into Google we get results related to terms such as 'cuisine' and 'dishes' and not to food products that can be bought from local producers.

Regulation (EU) No. 1151/2012 of the European Parliament and the Council [17] regulates issues related to foodstuffs labelled with the 'traditional specialty guaranteed' trademark. Whereas, the Council Regulation (EC) No. 510/2006 [18] defines regional products by referring to their origins. 'Designation of origin' or 'geographical indication' refer to the name of a region, a specific place or, in exceptional cases, a country used to label an agricultural product or a foodstuff [19]:

- $\quad$ originating in that region, specific place or country,

- the quality or characteristics of which are essentially or exclusively due to a particular geographical environment, and

- $\quad$ the production, processing and preparation of which take place in defined geographical area.

The most important characteristic of a regional food product is its high quality. It is a result of such products being manufactured using high quality ingredients. Additionally, characteristics of the products can be determined by climatic factors and natural topography. In the European Union, regional products are seen as special goods but also as European cultural heritage [20].

Food producers and marketers around the globe have long realized the importance of branding and labeling geographic associations of food products. This type of association often introduces price premia [21-24]. Regional products are certified using three designations: Protected Designation of Origin, Protected Geographical Indication, and Traditional Specialty Guaranteed. The first of the three is a symbol which specifies the name of the region, place or country used to describe an agri-food product originating from this place. In case of such products, their production as well as preparation should be carried out exclusively in the assigned area [25].

The right to use the Protected Geographical Indication certification is reserved for food products or agricultural products the name of which should be identified with a region, place, or country of its origin and production. In contrast to the Protected Designation of Origin here only one phase of production has to take place in a particular area [26].

According to the Council Regulation (EC) No. 509/2006 [27] traditional product is a product which has specific character-which means that it has one or a few characteristics that in some way make this agricultural product or foodstuff different from similar products or foodstuff belonging to the same category whereby, the characteristic or a few characteristics may refer to its physical, chemical, microbiological or organoleptic qualities, method of production, or specific production conditions [19]. As stated by Kupracz [28] traditional products can be defined as agricultural products, foodstuffs, and spirit drinks the quality or unique characteristics as well as properties of which are a result of using traditional production methods (on a small scale). These methods are considered to be traditional if they have been used for at least 25 years. In Poland, such products are put on the list of traditional products kept by the minister in charge of matters pertaining to agricultural markets.

As it can be concluded from the above considerations, regional product is most of all a certified product. Sometimes, its production is based on traditional formula and it is not mass produced. Similarly, traditional product is produced using traditional methods of production. Moreover, regional product is partially or entirely produced in a specific geographical area. Taking the above into account, how can we define a local product? Boros et al. [29] pointed out the attributes that characterize local food. They are as follows: 
- geographical distance between the place of production and the target consumer,

- methods of production that relate to environmental sustainability, e.g., reduce the use of synthetic chemicals and energy-based fertilizers,

- personality and ethics of the food producer, attractiveness of the farm as well as the landscape,

- strong social ties between farm-producer and the surrounding environment.

The above concept emphasizes the role of a farm which is also a producer of the local food. Meanwhile, some authors of publications use the term local food when referring to businesses owned by big producers. For example, Kokkinakisa et al. [30] took up the subject of producing local food in Greece (Crete). In his publication, he presented the functioning of the HACCP system in three large production facilities: ice-cream, ready-made sandwiches, and bottled water production facilities.

It is worth mentioning that the most used criteria for putting manufactured products into analyzed categories are place of production and perceiving products as being locally produced. Taking into consideration the geographical aspect, local food is food produced within $100 \mathrm{~km}$ from the place of residence of the buyer. Local products are associated more closely with a particular town or village than with a region [31]. What is important is that local products are protected by law [32]. Local products may become regional or traditional products [33].

Another important characteristic of local products is that they are manufactured on a small scale in environmentally friendly manner, and they use local ingredients [34]. As a result, this type of production is very profitable from the social, environmental, and economic point of view. Due to its originality, it can become a showpiece not only of a particular town but also of an entire region. This type of production is also a way of implementing the sustainable development policy. This concept is described as development, where the main focus is on fulfilling current needs while simultaneously caring for the needs of future generations and, to do so, it is required to protect natural environment [35].

Bearing in mind the above definitions of analyzed products, a comparison of regional, traditional, and local food and their examples was created and presented in Table 2.

Table 2. Comparison of regional, traditional, and local product based on the previously presented definitions (source: own study).

\begin{tabular}{|c|c|c|c|}
\hline Comparative Criterion & Regional Product & Traditional Product & Local Product \\
\hline EU Certification & Yes & Yes & Yes/No \\
\hline $\begin{array}{l}\text { Traditional manufacturing } \\
\text { method }\end{array}$ & Yes/No & Yes & Yes/No \\
\hline $\begin{array}{l}\text { Listed on the Traditional } \\
\text { Polish Products List }\end{array}$ & No & Yes & No \\
\hline $\begin{array}{l}\text { Associated with a specific } \\
\text { region }\end{array}$ & Yes & Yes & Yes \\
\hline $\begin{array}{l}\text { Production (all phases of } \\
\text { production) located in a } \\
\text { specific region }\end{array}$ & Yes/No & Yes/No & Yes \\
\hline $\begin{array}{l}\text { Ingredients originating from } \\
\text { in-house production }\end{array}$ & Yes & Yes/No & Yes/No \\
\hline Produced on a small scale & Yes & Yes & Yes/No \\
\hline Example & $\begin{array}{l}\text { Heather Honey from } \\
\text { Bory Dolnośląskie } \\
\text { (Poland), Parma } \\
\text { Ham (Italy), Cheddar } \\
\text { (Great Britain) }\end{array}$ & $\begin{array}{c}\text { Raspberry Syrup } \\
\text { from Dolina Baryczy } \\
\text { (Poland), Chorizo } \\
\text { (Spain) }\end{array}$ & $\begin{array}{l}\text { Strunga Winery Wines } \\
\text { (Romania), Černá Hora } \\
\text { Brewery Beers e.g., } \\
\text { Matouš (the Czech } \\
\text { Republic) }\end{array}$ \\
\hline
\end{tabular}


Data included in the table show that the definitions presented in literature and legal acts are fuzzy, which was already emphasized. Also, Granvik et al. confirmed that the interpretations and definitions of the term local food might be confusing and may lead to misunderstandings [36].

That is why, a new, own, and unambiguous definition of local food was created. Local food is a product or a preparation of the agri-food sector, non-certified, not mass produced, produced using best quality ingredients (from verified producers, who produce them in the same area), closely associated with the town or village where the production takes place, with consideration for the sustainable development policy.

Who then, is a local entrepreneur? As it was pointed out in the introduction, no coherent definition of local entrepreneurship was coined in source literature. There are also no regulations or norms which define such type of entrepreneurship. Analysis of the data from the Polish Central Statistical Office (GUS) and from portals devoted to local food producers indicated that it is difficult to estimate how big the general population is. GUS does not keep statistics pertaining to local enterprises (it only publishes figures encompassing the number of all enterprises in the region- divided according to their size).

Based on Sautet [37], it was concluded that local entrepreneurship is a socially productive activity which is limited to a small number of market transactions. It does not create a complicated division of work, it does not involve raising a substantial capital, and it is based on personal and informal relationships. Local entrepreneur/producer is in practice an entity which is a micro-enterprise, i.e., it employs less than 10 employees and has an annual turnover not exceeding 2 million euros [38]. He processes his ingredients using his own formula. In the course of the process he develops his passions thanks to which he can generate an additional or sole source of income.

\subsection{Description of Research Topics and Research Results in the Analyzed Area}

Analysis of the content of publications included in Table 1 allows for the conclusion that the research presented in scientific literature focuses on the following issues:

a. local food in the context of the idea of sustainable development $[7,39,40]$,

b. benefits of local food production [7,39],

c. transportation of local food and food supply chains [7,41-43],

d. supporting local food by governmental and non-governmental initiatives (i.e., educational programs, agri-food systems) [29,44-52],

e. consumers' perception of local food [7,52-58],

f. producers point of view on local food [53,59,60],

g. marketing of local products $[7,29,61]$,

h. safety of local food [30,62],

i. local food in the context of tourism [57,63-65],

j. $\quad$ health properties of local food [66-71].

First identified area of research encompasses the idea of sustainable development. Coelho et al. [7] addressed the problem pertaining to consumption of food produced locally with special consideration for sustainable development practices on both the local and global level. They pointed out that promoting such food is a complex problem that includes environmental issues, economy, and health. Moreover, they concluded that transport is not the only deciding factor when it comes to the volume of local food consumption. Technologies used in agricultural production have a much greater impact owing to the fact that they are responsible for the degree of sustainability of production and supplying food to people. They have also emphasized the fact that consumption of local food produced in a way that is in harmony with local environment and using ecological technologies is also beneficial for the economy and society.

In the research conducted by Edwards-Jones [39] special attention was given to the issue of following the sustainable development policy when producing local food and on the health-promoting qualities of local food. For that reason, the authors analyzed source literature looking for arguments 
confirming the environmental and health benefits of such food. The analysis indicated that no proof confirming this phenomenon was found. As a result, they came to the conclusions that in the future a more in-depth and comprehensive research should be conducted to analyze the issue more thoroughly.

Research devoted to the subject of transportation of local food and food supply chains was conducted by, i.e., Korhonen et al. [41]. They have characterized the issue of customers' interest in local food in Northern Ostrobothnia, Finland. Short food supply chains proved to be an important aspect of this research. The authors concluded that short food supply chains are the key to developing local food markets as they are connected to giving customers easier access to local food. In Finland, the local food program is an instrument which has been steering and supporting the national food policy since 2014. It has been implemented by means of administrative measures as well as development activities encompassing all entities in the local food chain. Logistic cooperation is highly organized around the typical production in Finland such as animal husbandry and milk production. Due to the fact, that logistics chains are highly oriented towards wholesale and retail there are some difficulties related to transporting local food to consumers. In this case, such food is distributed via very small operators, mainly by the farmers. The above-mentioned authors devised a method for analyzing the potential for integral networking of producers and transportation companies by combining qualitative and quantitative geographic information system (GIS)-based analysis.

Whereas, Romero-Lopez \& Ramos [43] searched for connections between producers and consumers in a small agricultural market in Mexico. They identified two short food supply chains used for selling eggs which reduced the distance between the producer and consumer, which in turn, enabled the exchange of information regarding, e.g., egg origin or egg production practices. Conducted research had a positive effect on increasing consumers' knowledge and trust in small-scale producers and their products. Moreover, the producer-consumer relationships in short chains allow for closeness, trust, and exchange of information.

The aspect that is closely associated with supporting agriculture is the aspect of agri-food systems. Sanz-Cañada \& Muchnik [51] described one of such systems namely Local Agro-Food Systems (LAFS) in North America and Europe. In the research on LAFS the term of local food origins is based on the historical and biocultural analysis of food identity. Belonging of such products to a particular place is determined based on natural, cultural, socio-economic, and demographic factors. Additionally, geographical and organizational proximity is important from the socio-cultural as well as economic point of view in the context of group actions aiming at developing rural areas. LAFS is a reflection of certain spatial density and a network of farms and enterprises cooperating in order to produce and introduce local products based on identity to the market. There is a need for an interdisciplinary view, where the emergence and the evolution of food based on identity is as important as understanding the role it plays in creating sustainable development of rural areas in the future. However, currently, not only the quality of products, their sensory properties or agri-food systems are important in promoting local food, what is also important is the innovativeness of such products. Authors devoted attention to that issue because food centers, food innovation districts as well as agricultural commodities markets are main examples of local gastronomy which can attract consumers. Thereby, they increase the interaction between communities, improve access to local healthy food and provide new market for small enterprises.

Another study conducted in North America (North Carolina) was devoted to local food systems created in the last 15 years. The authors pointed out that food hubs are part of an expanding network of local food distribution infrastructure aiming at helping small, local farms access not only local but also national market. However, the influence of food hubs on the region's developing food system is contradictory. It is so, because on one hand food centers contribute to developing local food supply chains and by that they create market opportunities for the farms, but on the other they may also work against bigger and long-term goals of the local food movement. Taking as an example the systems operating in the western North Carolina it was concluded that the food hubs are used as primary 
mechanisms for building local food systems and that building local food systems requires to engage people in the processes which can shape production, technology, and distribution of local food [50].

Other research conducted in North Carolina (the United States of America) in 2012 was also devoted to the issue of local food systems. Additionally, an attempt was made at estimating the willingness of consumers to pay for locally grown products. In relation to that, the authors carried out a survey which was divided into few sections i.e.,: current consumption of agricultural products, learning about the knowledge and opinions of the respondents ( 340 people) on the subject of local food and local food systems as well as socio-economic demographic characteristics (age, gender, level of education, etc.). Obtained results indicate that households are willing to pay $11 \%$ more for local products in comparison to agricultural products not produced locally. Introducing a local food system into a particular area may result in strengthening local food distribution networks. The analysis indicated that such system allows to foster economic development through agglomeration and clustering, improvement of the quality of life in the region, stimulating social capital formation, and it may be the basis for regional branding strategies [52].

Benedek and Balázs [45] analyzed the situation of local food systems (LFS) in Hungary. The authors have also described the food relocalization index (PIFRI-Policy Intervention for Food Relocalization Index) in order to quantitatively reveal how rural development program measures should be allocated efficiently to promote local food production. This index additionally points out underdeveloped areas that require further support and as a result it helps in setting goals of food policy. LFS in Hungary is in the early stages of development. Only in Budapest it is involved in short food supply chains. In their research paper, the authors concluded that PIFRI may be a valuable and easy tool to be used for mapping local food activity and may support rural development planning processes in Hungary. Other authors who focused their attention on food systems are Papaoikonomou and Gineis [49]. They focused their attention on two other systems: Community Supported Agriculture in Manhattan, New York and Responsible Consumption Cooperatives in Catalonia, Spain which allowed them to study the relationship between producers and consumers of local food.

Ballantyne-Brodie \& Telalbasic [44] focused their attention on the issue of ensuring that society has possibility to implement food systems and studied ways to effectively design post-capitalist models for food systems. In order to do so, they described three case studies characterizing the following systems: 'Shepparton', 'Dandenong', and 'Coltivando'. The first of the three systems was created in Regional Victoria, Australia. It was created due to the serious economic issues resulting from cheap importation of fruit. The second system pertains to food strategies of the City of Greater Dandenong, Metropolitan Melbourne (Australia). The local food strategy was designed in order to support food policy. The last of the three systems was created in Politecnico di Milano, Italy. This project led to establishing urban agriculture. The first of the three projects was carried out on the premises of the university garden. Described cases show that local institutions are changing their attitudes towards citizens and vice versa. The ability to adjust to socio-economic changes is the key here, as it drives the business design process of local food systems to generate sustainable and scalable models. The model creates a platform for building capacities by strengthening the position of local people in order for them to take an active part in setting up food systems.

Whereas, the results of the study conducted by Lutz et al. [47] show that cooperation between farmers is a good way of creating local food systems in Australia. The study demonstrated that local production infrastructure, processing, and distribution are becoming more approachable when farmers cooperate with each other, consumers and institutions. Additionally, the authors pointed out that sharing knowledge helps to optimize local agriculture and food supply systems (farmers are often lacking knowledge and time to establish new cooperation or to reorganize work, distribution, and communication).

Martinez [48] raised the issue of federal, state, and local policy in the United States of North America in the context of supporting local food systems. Local food was linked to several government actions, i.e., improving rural economy and supporting agricultural producers. What is important is that 
United States policy lowers the barriers that inhibit further growth of local food markets, e.g., lack of infrastructure for increasing local food sales, producers lacking sufficient knowledge. Positive actions that should be taken up in this context are: increasing small farms' production, fulfilling the needs of bigger retail outlets, creating ability to track the origins of the product, and educating producers on the subject of local food expansion.

An important part of research on local food is related to consumer preferences. For example, in Italy a survey was carried out in order to assess factors influencing consumers' perceptions of Riso e Rane Carnaroli. Preliminary research results revealed that consumers are more aware of such information as: the origins of the product, local food system, and tradition, than for example DNA tested certification [55]. Rytkönen et al. [57] focused on the issue of identifying preferences as well as factors motivating consumers and tourists to buy local artisanal cheese in Jämtland (Sweden). They have conducted two surveys in Östersund. The place where the survey was conducted was selected based on the fact that farms, farm cafés, and markets are the main sales channels for dairy. The research determined that respondents appreciate combinations of various attributes defined as MDDPS-market-driven direct produce system; and CTS—close typicity system. In MDDPS, it was determined that the nature of relationships between producers and consumers can be specified by the level of common knowledge between the buyers and sellers. In this system, the involvement of consumers is often a result of searching for unconventional food production. In CTS, it is the relationship between the product and region that plays the central role when it comes to consumer deciding to buy a product. Moreover, the survey revealed that respondents choose local products firstly, because of their 'good taste 'and 'high quality'. The authors also concluded that purchasing this type of food is very often determined by tradition and historical ties of the consumers with the region in which local products are being produced.

Similar subject was taken up by Albrecht and Smithers [53]. They conducted a survey among 13 producers of local food (meat products) and 31 consumers in the Southwestern Ontario (Canada) between June and September of 2013. The area of their research was focused on identifying ways in which farmers shape 'value' and 'quality' of the manufactured products and assess the preferences for such products (questions pertained to farm size, produced goods, and the frequency of the consumer/producer interaction). Whereas, when it comes to consumers the authors focused on their opinions, expectations, and motivations for buying local food. Therefore, they were looking for factors that could bring the two studied groups together. Collected information enabled the authors to formulate conclusions which indicated that making connections between producers of local food and consumers is appreciated by both parties in terms of profitability (producers) and the health-promoting nature of the manufactured products (consumers). Authors came to the conclusion that creating connections between producers and consumers is determined by what both groups have to offer to each other (sharing collected knowledge, raising awareness of local products, and various partnerships between producers).

Another research devoted to the issue of consumers' interest in local food was conducted by $\mathrm{Lim}$ and $\mathrm{Hu}$ [56]. Their aim was to determine consumers' demand for local food (pork chops, local beef) and point out barriers for purchasing such types of food. A survey was conducted with 1406 respondents from Connecticut (North America). Results of the survey revealed that the most crucial purchasing barrier is the price and availability of local products. The authors drew attention to the health-promoting properties of such food products suggesting that they may be helpful in fighting with obesity in the United States. Crespo et al. [54] focused their attention on the role of social capital in developing the region. They have concluded that nowadays farmers have to face the challenge of product certification that would allow local society to transform their resources and the know-how into new market opportunities.

Halldórsdóttir and Nicholas [40] conducted research which focused on identifying behavioral barriers influencing production and consumption of local food in Iceland. The authors assessed the structure of pro-ecological behaviors which result in purchasing local food in the context of three 
groups of factors: structural (sustainable production), cultural, and personal (sustainable consumption). With that in mind they have analyzed the survey data on cultural norms and purchasing behaviors of local food consumers. The data was obtained from the Matis research and development company. As a result of the conducted research they came to the conclusion that two-thirds of the respondents find it important to support local agriculture (in the context of environmentally friendly production). They have also identified barriers which decrease demand for local food. They were as follows: decrease in variety of food (structural barrier) and skepticism of the consumers (as a barrier hindering the growth of consumption of such food).

The significance that local food has for the modern consumer was described in the research carried out by Litavniece et al. [72]. Their goal was to study local food choices and how they are used by modern consumers. Over 500 respondents from Łatgalii (Latvia) took part in the research which was conducted in 2017. The survey was conducted in order to assess the extent of people's knowledge on the subject of local as well as functional and ecological food. Additionally, they asked how often are the responders choosing local food and what is their attitude towards that choice. The results revealed that consumers pay attention to the quality of food, date of production and price. They have also concluded that responders are regularly purchasing food from local producers.

While in the research conducted by Wenzing and Gruchmann [58], who studied preferences of consumers vis-à-vis local food, (327 respondents took part in the research) the researchers demonstrated that respondents have some limitations when it comes to buying local food that are related to lack of knowledge in this area.

Another important issue associated with local food is related to producers promoting their products, e.g., via educational programs. This issue was described by local food researchers in Spain. They aimed to recognize and characterize activities promoting purchase of local food intended for schools and local education centers. They were looking for governmental and non-governmental initiatives which organize programs that promote this type of food in schools and other autonomous communities. The non-governmental initiatives were found on the internet and were analyzed in terms of their geographical distribution, organizational area, number of schools, management style, and purchasing local food. In the course of the research, they identified 12 (6 governmental and 6 non-governmental) initiatives that were carried out by 318 schools (which constitutes $2.16 \%$ of all Spanish schools which have their own food services). They have concluded that local initiatives promoting buying food in Spain have limited scope [61].

Boros et al. [29] have also focused their attention on the way local food product manufacturers are promoted by the trading policy of one of the largest Hungarian food retailer chains. They conducted a supplementary analysis in categories which offered very few regional food products. They came to a conclusion that the percentage of sales of products produced locally is higher in these categories in which production is less complicated and the role of complex marketing is less important. In those categories where professional marketing tools or production procedures are required the existing producers were able to keep their significant market position. The authors drew attention to the need to produce food of the highest quality after scandals related to bad quality of products. Therefore, the government of Hungary realized that there is a necessity to create new legal conditions to define local food. This decision led to creation of 'Hungaricum Act' which describes the typical Hungarian traditional food and 'Local Product Act' which determines which products could be called local.

In North America (State of Michigan) in 2013 a project under the name of Grand Rapids Downtown Market (DTM) was developed in order to create space for producing local food, entrepreneurship, supporting health of the community, and providing work places. The aim of the project was to ensure that consumers have the possibility to buy healthy food. Creation of this concept allowed to promote local food systems to boost economy by agglomeration of small producers located in the region. Food innovation districts are supposed to stimulate job growth, increase healthy food options, and create a 'sense of place', concentrating on improving the quality of life of local residents [46]. 
The next area of research associated with local food is the issue of local food security. Burke et al. [62] in their research focused on local food stored in traditional storage cellars in Alaska (North America). They focused their attention on food stored by the poorest section of society living in rural areas. This section of society includes in their diet foods that are mostly natural and made at home. They conducted interviews on the basis of which they determined that food stored in storage cellars is microbiologically safe.

Another issue related to local food production is tourism. Although there are many studies on behaviors of tourists, they rarely take into consideration the influence of local food on tourists' experiences. Demand for local food generated by tourists occurs on many levels of intensity. For that reason, tourists could be divided into those who travel around the region for gastronomic reasons and those who treat local food just as an addition to their experience. Sengel et al. [65] studied factors that have influence on choosing local food by tourists in various parts of the Old Town of Istanbul. They have concluded that the issue of food tourism is important because it is a new trend and also because gastronomy has started to be recognized as a symbolic value representing territories and culture in tourism. Beforehand, local food was considered to be an additional rather than the main attraction of the visited place. Culinary tourism, beyond the dishes offered by a region, encompasses getting to know local food producers, visiting food festivals, restaurants, as well as purchasing local products directly from producers. According to Forné [63] food tourism is currently one of the most important and specialized tourist niches. Tourism benefits from traditional farming and breeding in the context of rural tourism. Local gastronomy reflects the fusion between natural and cultural characteristics of the region. Therefore, culinary heritage has to act as a source of local development by overcoming the seasonal character of demand for tourism. It is then necessary to aim for balance, so that the citizens and tourists could live in a region in a sustainable way.

The issue of culinary tourism was also taken up by Madaleno et al. [64]. The authors conducted an empirical study in Portugal (Lisbon, Porto, and Coimbra) in 2015. The study involved 500 respondents. The aim of the study was to specify the factors which have influence on the decision to purchase local food products by foreign guests from Portugal. It was determined that approximately $84 \%$ of respondents enjoy buying local food during their travels. The factors that influence tourists when they make the decision to purchase food are related to their personality and their motivation to make a purchase as well as determining relationships between the place of production and the local product itself. It turned out that the authenticity as well as the appearance of local food has a positive influence on the decisions of the consumers. They have then pointed out that certification of local products should be taken into consideration when specifying the policy actions promoting local products.

In the research conducted in North America (Southwestern Ontario) authors drew attention to the issue of local food in the context of its health promoting properties. For that purpose they created a research project promoting this type of food by means of using an application designed for smartphones named 'SmartAPPetite'. The application was designed to encourage healthy dietary behaviors by reducing educational, behavioral, and economic barriers. SmartAPPetite proved to be effective in improving awareness and consumption of healthy food and it also drew people to local food producers more frequently than traditional measures [67].

In another study focused on describing the problem of obesity, authors compiled an overview of literature (review research) and described conceptual framework characterizing the health-promoting indicators of local food. They have found 177 research papers which correspond with the subject in question. The research demonstrated that obesity is a result of lack of energy balance (from the ingested food) and little physical activity (sedentary lifestyle) [69].

Morland and Evenson [68] as well as Pelletier et al. [70], and Cobb et al. [66] described the issue of consumer obesity and confronted it with consumption of local food. Each of the research was conducted in the United States. The authors of the first and the second paper carried out surveys where 1295 respondents took part in the 2003 survey and 1201 respondents took part in the 2010 survey respectively. In case of the first study, the authors concluded that prevalence of obesity was lower in 
areas that had supermarkets and higher in areas with small grocery stores or fast food restaurants. The second study determined that approximately half of the respondents gave local food high marks. Additionally, respondents who pay a lot of attention to purchasing local food consume much more fruit and vegetables, dietary fiber, and less sugar and fat in comparison to people who do not pay attention to the food they purchase. The last paper used a review of literature pertaining to the described issue as the research method. They have found 71 matching papers which proved that there are no links between presence of food establishments and obesity. Table 3 presents geographical areas where research on local food is most prevalent.

Table 3. Research topics related to local food taking into account the geographical areas (source: own study).

\begin{tabular}{|c|c|}
\hline Research Topics & Geographical Area \\
\hline Local food in and the idea of sustainable development & USA, Brazil, Great Britain, Iceland \\
\hline Benefits of local food production & USA, Brazil, Great Britain \\
\hline Transportation of local food and food supply chains & USA, Brazil, Great Britain, Scotland, Finland, Mexico \\
\hline $\begin{array}{l}\text { Supporting local food by making use of } \\
\text { governmental and non-governmental initiatives (i.e., } \\
\text { educational programs, agri-food systems) }\end{array}$ & $\begin{array}{c}\text { Europe with particular reference to Hungary, Spain, } \\
\text { and Austria, Australia, USA }\end{array}$ \\
\hline Consumers' perceptions of local food & $\begin{array}{l}\text { USA, Canada, Mexico, Brazil, Italy, Sweden, Iceland, } \\
\text { Latvia, Germany }\end{array}$ \\
\hline Local food from the producer's point of view & USA, Canada \\
\hline Marketing of local products & USA, Brazil, Spain, Hungary \\
\hline Safety of local food & USA, Greece \\
\hline Local food in the context of tourism & Turkey, Spain, Portugal, Sweden \\
\hline Health properties of local food & Australia, USA, Canada \\
\hline
\end{tabular}

The conclusion based on the data from Table 3 is that issues relating to the subject of local food production are taken up most frequently by researchers from the USA. Researchers from European countries are focusing mainly on: issues relating to tourism (Spain, Portugal), food safety (Greece), and marketing (Spain, Hungary) as well as the meaning that the local food has for the consumer (Italy, Sweden, Iceland, Latvia, and Germany), and the idea of sustainable development (Great Britain).

\section{Discussion and Directions for Further Research}

Literature review revealed definitional discrepancies related to the subject of the study. The analysis of the publications proved that the issue of local entrepreneurship in the context of food production was not fully explored.

Most of the available publications are devoted to local food produced in the United States, Canada, Hungary, Greece, etc. Local food is often defined as food produced by a big enterprise in a particular area. Critical literature review revealed significant insights provided by prior research. In the analyzed research papers the problem of local food is most often correlated with its marketing or health promoting properties. However, examples of supporting local production and distribution provided in the publications may serve as a benchmark for initiatives undertaken in other countries. For example, in Poland governmental and non-governmental initiatives—such as in Spain — which organize programs that promote local food in schools are needed [61]. One can use the list of health indicators prepared by Murphy et al. [69] and a similar application to above-presented 'SmartAPPetite' [67] in order to make education more attractive for youth (generation Z). Moreover, network of producers and transportation companies can be improved by means of using a dedicated geographic information system, such as the system that has been implemented in Finland [41]. 
While looking for research problems which could be raised in empirical research in the interest of mobilizing local entrepreneurship (important for the development of the region) it was concluded that there is a lack of publications pertaining to:

(a) types of local entrepreneurship

(b) determinants of local entrepreneurship in the context of food production

There are many typologies of entrepreneurship that can be found in source literature. Examples of definitions were presented in Table 4. It would be interesting to inter alia explore the scope of cooperation between local enterprises and academic centers, explore the manner of conducting a business (traditional vs. virtual/internet based) or the degree to which the entrepreneurs act in an ethical manner (i.e., care about the quality of the product even at the expense of decreasing revenue). As stated by Lutz et al. [47], farmers are often lacking knowledge and time to establish new cooperation or to reorganize work, distribution, and communication. The issue can be studied further from different perspectives, e.g., reasons for cooperation/non-cooperation with universities or correlation between specific family business culture and implementation of the idea of open innovation. Other implications for further research are presented in Table 4.

Table 4. Types of entrepreneurship in the context of local food production (source: own study on the basis of $[14,73-82])$.

\begin{tabular}{|c|c|c|}
\hline Type of Entrepreneurship & Characteristics & $\begin{array}{l}\text { Implications for Local Food } \\
\text { Production and Further Research }\end{array}$ \\
\hline Academic Entrepreneurship & $\begin{array}{l}\text { Entrepreneurship is based on the } \\
\text { knowledge possessed by the members } \\
\text { of the academic world. }\end{array}$ & $\begin{array}{l}\text { Implementation of academic } \\
\text { knowledge in local food } \\
\text { production as a way of } \\
\text { introducing innovation }\end{array}$ \\
\hline Family Entrepreneurship & $\begin{array}{l}\text { Family entrepreneurship is the type of } \\
\text { entrepreneurship where the owner } \\
\text { and the employees are family } \\
\text { members (one-generation or } \\
\text { multigenerational family). }\end{array}$ & $\begin{array}{l}\text { Family business in the context of } \\
\text { propensity for implementing the } \\
\text { idea of open innovation }\end{array}$ \\
\hline Innovative Entrepreneurship & $\begin{array}{l}\text { Is based on implementing (in the } \\
\text { enterprises) new and pioneering } \\
\text { solutions new technologies and } \\
\text { products. }\end{array}$ & $\begin{array}{l}\text { Local food producers as pioneers. } \\
\text { Implementation of design thinking } \\
\text { concept in local food production. }\end{array}$ \\
\hline Social Entrepreneurship & $\begin{array}{l}\text { Is based on actions focused on social } \\
\text { integration in the aspect of local } \\
\text { community and preventing social } \\
\text { exclusion e.g., by implementing } \\
\text { employment support programs. }\end{array}$ & $\begin{array}{c}\text { Implementation of Management } \\
\text { by Values as basis for } \\
\text { sustainability in local food } \\
\text { production }\end{array}$ \\
\hline Internet Entrepreneurship & $\begin{array}{l}\text { Internet entrepreneurship's economic } \\
\text { activity is focused on e.g., selling } \\
\text { products or services online. }\end{array}$ & $\begin{array}{l}\text { Local food products and their } \\
\text { delivery in the context of } \\
\text { preferences of new generations } \\
\text { (generation Y, generation Z) }\end{array}$ \\
\hline Ecological Entrepreneurship & $\begin{array}{l}\text { It encompasses all entrepreneurial } \\
\text { activities beneficial for the natural } \\
\text { environment e.g., production waste } \\
\text { management. }\end{array}$ & $\begin{array}{l}\text { Implementation of Management } \\
\text { by Values and modern methods } \\
\text { connected with environmental } \\
\text { sustainability in local food } \\
\text { production }\end{array}$ \\
\hline Ethical Entrepreneurship & $\begin{array}{l}\text { Ethical entrepreneurship is a type of } \\
\text { entrepreneurial activity in which } \\
\text { ethical values such as high quality of } \\
\text { products is more important than the } \\
\text { economic value. }\end{array}$ & $\begin{array}{l}\text { Management by values in local } \\
\text { food production (which values } \\
\text { dominate in the management } \\
\text { philosophy of local food } \\
\text { producers) }\end{array}$ \\
\hline
\end{tabular}


When considering the 'social' type of entrepreneurship one can conclude that the relationship between commercial entrepreneurship and social entrepreneurship has been studied in literature devoted to this field of research. To give an example, the commercial entrepreneurship can create social value by generating economic wealth [2]. The findings of Mars and Schau revealed that the commercial and social variations of local food entrepreneurship are assorted, yet synergistic enactments of the economic, environmental, and social conditions and principles that characterize the southeastern Arizona local food system. It would be worth conducting research on specific management concepts (e.g., management by values) and their application in practices of local food producers to create ethical, ecological, and social business [83].

In order to find ways of mobilizing local entrepreneurs it would be worth conducting research on the subject of determinants of entrepreneurship. The determinants can be divided into external and internal (personal) determinants. External determinants are the characteristics of socio-economic environment of the enterprise. Availability of capital, systems of economic and legal policies, national and international entrepreneurship support programs, systems of education and training, etc. are some of the external determinants. Internal determinants are the qualities possessed by an entrepreneur. Table 5 presents examples of internal and external determinants of entrepreneurship.

Table 5. Characteristics of selected determinants of entrepreneurship in the context of local food production (source: own study based on: [84-93]).

\begin{tabular}{|c|c|c|}
\hline $\begin{array}{l}\text { Determinants of } \\
\text { Entrepreneurship }\end{array}$ & Characteristics & $\begin{array}{l}\text { Implications for Local Food } \\
\text { Production and Further Research }\end{array}$ \\
\hline \multicolumn{3}{|c|}{ Internal } \\
\hline $\begin{array}{l}\text { ‘Hard' elements of } \\
\text { human potential }\end{array}$ & $\begin{array}{l}\text { Examples of such elements are: age, } \\
\text { gender, education, professional } \\
\text { qualifications. }\end{array}$ & \multirow[b]{2}{*}{$\begin{array}{l}\text { Correlations between "hard" and } \\
\text { "soft" elements of human potential } \\
\text { and type of entrepreneurship (see } \\
\text { Table 4). Examples: } \\
\text { the level of qualification vs. the } \\
\text { openness to cooperation with } \\
\text { universities or willingness of } \\
\text { implementation of the idea of open } \\
\text { innovation, honesty as a predictor } \\
\text { of ethical entrepreneurship }\end{array}$} \\
\hline $\begin{array}{l}\text { 'Soft' elements of human } \\
\text { potential }\end{array}$ & $\begin{array}{l}\text { - Character traits of an entrepreneur: } \\
\text { communication skills, diligence, honesty, } \\
\text { assertiveness etc. } \\
\text { - Personality of an entrepreneur: } \\
\text { sanguine, choleric, melancholic or } \\
\text { phlegmatic person } \\
\text { - Attitudes of the entrepreneur: } \\
\text { optimism, pessimism, pioneering attitude, } \\
\text { conservative attitude, creative abilities, } \\
\text { and lack thereof etc. }\end{array}$ & \\
\hline \multicolumn{3}{|c|}{ External } \\
\hline $\begin{array}{l}\text { Economic (micro- and } \\
\text { macroeconomic) }\end{array}$ & $\begin{array}{l}\text { e.g., availability of capital, taxes, } \\
\text { availability of a loan, exchange rate, } \\
\text { market fluctuations. }\end{array}$ & \multirow{6}{*}{$\begin{array}{l}\text { Which determinants are the most } \\
\text { important stimulators and barriers } \\
\text { for local food entrepreneurship in } \\
\text { particular region/country/business } \\
\text { (e.g., local wine production)? } \\
\text { What activities should be taken by } \\
\text { local government in order to } \\
\text { stimulate local food } \\
\text { entrepreneurship? } \\
\text { If there is possibility of } \\
\text { implementation of governmental } \\
\text { and non-governmental initiatives } \\
\text { which are undertaken in foreign } \\
\text { countries. }\end{array}$} \\
\hline Institutional & $\begin{array}{l}\text { Efficiency of administration, business } \\
\text { organizations, guarantee funds, business } \\
\text { advisory, system of education }\end{array}$ & \\
\hline Formal and legal & $\begin{array}{l}\text { e.g., suitable procedures, norms, } \\
\text { and decrees, licenses and certifications. }\end{array}$ & \\
\hline Socio-cultural & $\begin{array}{l}\text { Social mobility and openness, status, } \\
\text { socio-political climate, level of education, } \\
\text { criteria for social mobility, and level of } \\
\text { social optimism. }\end{array}$ & \\
\hline Geographical & $\begin{array}{l}\text { e.g., regional climate, typical soils, } \\
\text { landform. }\end{array}$ & \\
\hline Technological & $\begin{array}{l}\text { Technological changes in production of } \\
\text { goods and services. }\end{array}$ & \\
\hline
\end{tabular}


The local food producers, especially those who allow for in-site tasting, have a strong implication for the structure of local product added-value chain because they satisfy consumers' preference and needs [94]. They also contribute to the health of community members and the economic livelihood of small farms [88]. Engelseth suggests that local food supply is "personal" and associated with proximity makes it more closely resemble service supply chains [95]. Local markets are the platform where people share memories, experiences, stories, and values based on trust [96]. Abatekassa and Peterson stated that local producers need to provide additional market services and develop relationships with their buyers based on trust to create better market access for local foods [97]. Schmit et al. indicated that sufficient engagement between local producers and urban consumers, combined with educational programming by the farmers market, can increase the transmission of intellectual capital flows to rural areas [89]. However, the local food business often suffers from a lack of economic viability [98]. Boys and Fraser indicated that practical marketing considerations, such as payment terms, and processing, packaging and delivery requirements of supplying institutional foodservice buyers, were identified as obstacles to the efficient function of this market channel [93]. Food safety challenges, including the related issues of obtaining (food) products liability insurance and food safety certifications, were also acknowledged among top concerns [93]. High transaction costs for direct exchange, however, impede growth in the direct market channel [99]. Small farms face extreme difficulties in reaching formal market channels and therefore rely on subsistence and informal sales [91]. The producers of local food are often small, and many are facing bottlenecks in logistics and transport when trying to expand their business [100] They need to integrate within networks of suppliers, distributor, customers, and community representatives to increase their competitiveness [101,102]. Direct marketing is a widespread marketing practice among smaller producers. Packing and grading standards, sampling and consumer premiums (marketing factors) can also affect the profitability [103]. Scale, production enterprise specialty, market outlet choices, land ownership, and management of expenses have the most significant influence on producer financial efficiency [104]. The number of farmers and producers selling through local food markets is growing.

Community-supported agriculture is a unique local food channel adopted by producers. It was initially established as a strategy for producers to directly benefit from the season-long investments of buyers who align with their community-focused mission [92]. Local food system development is a popular strategy employed by many communities in the pursuit of sustainable and equitable economic growth and development. This strategy includes a range of economic projects, including farmers' markets, community-supported agriculture enterprises, urban farming/agriculture projects, and food hubs. Sometimes, it includes intermediated marketing channels like grocery stores and broad-line distributors interested in providing local foods [105]. Short food supply chains are now widely believed to be more sustainable in comparison to mass food delivery systems [106]. Development of short food supply chains may help to provide various benefits support of the local economy, the strengthening of relations between consumers and their food traditions, the supply of fresher food products in comparison to conventional food networks, the re-valuation of the small-scale farmer's role in the food systems, the use of sustainable production methods and the reduction of $\mathrm{CO}_{2}$ emissions [107]. Nevertheless, farmers' engagement in short food supply chains' is still limited in many countries [108].

As it was pointed out earlier, the conducted source literature review determined that various authors focus in detail on issues connected with local food production. For example, the subject of supporting local production by means of governmental and non-governmental initiatives has been discussed. Consumers' perceptions of local products are also important. However, institutional support and consumers' opinions are only two of the many determinants of entrepreneurship. Before introducing public initiatives, it is worth to conduct research on determinants which are the most important stimulators and barriers for local food entrepreneurship in particular region/country/business (e.g., local wine production). One can conduct further research including a combination of a variety of issues. An example of such research topic could be joint influence of different public initiatives with the moderating role of specific elements of entrepreneurs' human potential on business results. 
The above described lines of research may be taken up globally or may be based within specific country or region or may be focused on production of particular food products. As it was determined by the source literature studies, research on the subject of local food conducted in Central and Eastern Europe is sparse.

\section{Conclusions}

Local food production is meaningful not only for single producer but also for the consumer, and finally for the entire region. Therefore, it would be beneficial to take up the issue of local entrepreneurship in the context of food production. The need to define local food and local entrepreneurship in an unambiguous way was emphasized in the study and own definitions of the issues were provided. An analysis of the research topics undertaken in papers published after 2005 and indexed in the Web of Science database was conducted. Local food is associated with, i.e., its health promoting properties as well as the idea of sustainable development. The authors have also investigated the subject of local food transportation and delivery chains. Many forms of local production supported by means of governmental and non-governmental initiatives are widely featured in literature. Tourism associated with learning about local food is a relatively new research subject.

There are many practical implications of the source literature review, related to, e.g., implementing local food production support programs. Whereas, we identified research gaps that created room for further empirical research on the subject of, e.g., cooperation of local entrepreneurs with academic world, ethicality of activities performed by the local producers, and numerous determinants of entrepreneurship. It would also be worthwhile to conduct research in the 'neglected' geographical areas such as Central and Eastern Europe. Conducting the above-mentioned research would be valuable not only from the scientific point of view but also from a practical one-it could contribute to the development of local entrepreneurship and thereby, to the development of the entire regions.

Author Contributions: I.K., K.P.-S., M.K. conceptualization, I.K., K.P.-S., M.K. methodology, I.K., K.P.-S., M.K. writing - original draft preparation, I.K., K.P.-S., M.K. review and editing. All authors have read and agreed to the published version of the manuscript.

Funding: The project is financed by the Ministry of Science and Higher Education in Poland under the programme "Regional Initiative of Excellence" 2019-2022 project number 015/RID/2018/19 total funding amount 10721 040,00 PLN.

Conflicts of Interest: The authors declare no conflict of interest.

\section{References}

1. Lans, T.; Seuneke, P.; Klerkx, L. Agricultural entrepreneurship. In Encyclopedia of Creativity, Invention, Innovation and Entrepreneurship; Carayannis, E.G., Ed.; Springer: Washington, DC, USA, 2013; pp. 1-7.

2. Migliore, G.; Schifani, G.; Romeo, P.; Hashem, S.; Cembalo, L. Are Farmers in alternative food Networks social entrepreneurs? Evidence from a behavioral approach. J. Agric. Environ. Ethics 2015, 28, 885-902. [CrossRef]

3. Pindado, E.; Sánchez, M. Researching the entrepreneurial behaviour of new and existing ventures in European agriculture. Small Bus. Econ. 2017, 49, 421-444. [CrossRef]

4. Alsos, G.; Carter, S.; Ljunggren, E.; Welter, F. Introduction: Researching entrepreneurship in agriculture and rural development. In The Handbook of Research on Entrepreneurship in Agriculture and Rural Development; Alsos, G.A., Carter, S., Ljunggren, E., Welter, F., Eds.; Edward Elgar: Cheltenham, UK, 2011; pp. 1-20.

5. Grande, J.; Madsen, E.L.; Borch, O.J. The relationship between resources, entrepreneurial orientation and performance in farm-based ventures. Entrep. Reg. Dev. 2011, 23, 89-111. [CrossRef]

6. Dias, C.S.L.; Rodrigues, R.G.; Ferreira, J.J. What's new in the research on agricultural entrepreneurship? J. Rural Stud. 2019, 65, 99-115. [CrossRef]

7. Coelho, F.C.; Coelho, E.M.; Egerer, M. Local food: Benefits and failings due to modern agriculture. Sci. Agric. 2018, 75, 84-94. [CrossRef] 
8. Hjorth, D.; Steyaert, C. Entrepreneurship beyond (a new) economy: Creative swarms and pathological ones. In New Movements in Entrepreneurship; Steyaert, C., Hjorth, D., Eds.; Edward Elgar: Cheltenham, UK; Northampton, MA, USA, 2003; pp. 286-304.

9. Drozdowski, G. Przedsiębiorczość w świetle współczesnych koncepcji zarządzania kapitałem ludzkim. Pr. Inst. Prawa i Adm. PWSZ w Sulechowie 2006, 2, 223-229.

10. Wiatrak, P.A. Pojęcie przedsiębiorczości, jej cele i rodzaje. In Uwarunkowania Rozwoju Przedsiębiorczości-Szanse i Zagrożenia; Jaremczuk, K., Ed.; Państwowa Wyższa Szkoła Zawodowa w Tarnobrzegu: Tarnobrzeg, Poland, 2003; pp. 26-27.

11. Griffin, J. First steps in an account of human rights. Eur. J. Philos. 2001, 9, 306-327. [CrossRef]

12. Yetisen, A.K.; Volpatti, L.R.; Coskun, A.F.; Cho, S.; Kamrani, E.; Butt, H.; Khademhosseini, A.; Yun, S.H. Entrepreneurship. Lab Chip 2015, 15, 3638-3660. [CrossRef] [PubMed]

13. Morris, M.H.; Sexton, D.; Lewis, P. Reconceptualizing entrepreneurship: An input-output perspective. SAM Adv. Manag. J. 1994, 59, 21-31.

14. Piwowar-Sulej, K.; Kwil, I. Przedsiębiorczość, przedsiębiorczość akademicka i technologiczna, innowacyjność-próba systematyzacji. Przegląd Organ. 2018, 7, 18-24. [CrossRef]

15. Sakhdari, K. Corporate Entrepreneurship: A review and future research agenda. Technol. Innov. Manag. Rev. 2016, 6, 5-18. [CrossRef]

16. Julien, P.-A. A Theory of Local Entrepreneurship in the Knowledge Economy; Publishing, E.E., Ed.; MPG Books Ltd.: Bodmin, UK, 2007.

17. Council of the European Union; European Parliament. Regulation (EU) No 1151/2012 of the European Parliament and of the Council of 21 November 2012 on Quality Schemes for Agricultural Products and Foodstuffs; 32012R1151; Publications office of the European Union: Brussels, Belgium, 2012.

18. Council of the European Union. Council Regulation (EC) No 510/2006 of 20 March 2006 on the Protection of Geographical Indications and Designations of Origin for Agricultural Products and Foodstuffs; 32006R0510; Publications Office of the European Union: Brussels, Belgium, 2006.

19. Newerli-Guz, J.; Rybowska, A. Produkt tradycyjny i regionalny - luksus od święta czy na co dzień? Handel Wewnętrzny 2015, 2, 286-295.

20. Gulbicka, B. Żywność Tradycyjna i Regionalna w Polsce; Instytut Ekonomiki Rolnictwa i Gospodarki Żywnościowej-Państwowy Instytut Badawczy: Warszawa, Poland, 2014; ISBN 9788376584959.

21. Alfnes, F.; Rickertsen, K. Extrapolating experimental-auction results using a stated choice survey. Eur. Rev. Agric. Econ. 2007, 34, 345-363. [CrossRef]

22. Henseleit, M.; Kubitzki, S.; Teuber, R. Determinants of consumer preferences for regional food. In Proceedings of the European Association of Agricultural Economists, 105th Seminar, Bologna, Italy, 8-10 March 2007; p. 14.

23. Hu, W.; Qing, P.; Batte, M.; Woods, T.; Ernst, S. What is local and for what foods does it matter? Agric. Econ. 2013, 59, 454-466. [CrossRef]

24. Lobb, A.E.; Arnoult, M.H.; Chambers, S.A. Willingness to Pay for, and Consumers' Attitudes to, Local, National and Imported Foods: A UK Survey; The University of Reading: Reading, UK, 2006.

25. Lemanowicz, M.; Szwacka-Mokrzycka, J. Innovation activities of food industry enterprises. Zesz. Nauk. Szk. Głównej Gospod. Wiej. Warszawie 2014, 12, 110-121.

26. Borowska, A. Unijny system ochrony żywnościowych produktów regionalnych i tradycyjnych. Zesz. Nauk. SGGW Ekon. Organ. Gospod. Żywnościowej 2008, 71, 107-122.

27. Council of the European Union. Council Regulation (EC) No 509/2006 of 20 March 2006 on Agricultural Products and Foodstuffs as Traditional Specialities Guaranteed; 32006R0509; Publications office of the European Union: Brussels, Belgium, 2006.

28. Kupracz, M. Z problematyki żywności tradycyjnej. Stud. Reg. Lokal. 2007, 4, 99-115.

29. Boros, P.; Bogóné-Tóth, Z.; Fehér, O. The economic and marketing importance of local food products in the business policy of a Hungarian food retail chain. Procedia Soc. Behav. Sci. 2013, 81, 589-594. [CrossRef]

30. Kokkinakis, E.; Kokkinaki, A.; Kyriakidis, G. HACCP implementation in local food industry: A survey in in Crete, Greece. Ital. Oral Surg. 2011, 1, 1079-1083. [CrossRef]

31. Jaworski, M.; Dominik, P. Kontekst przyrodniczy powstawania tradycyjnych produktów kulinarnych jako wartość dla turystyki kulturowej. ZNUV 2017, 54, 55-73. 
32. Schmit, J. Locally Grown Food Sounds Great, But What does it Mean? Available online: https://usatoday30. usatoday.com/money/economy/2008-10-27-local-grown-farms-produce_N.htm (accessed on 31 May 2019).

33. Bryła, P. Regional ethnocentrism on the food market as a pattern of sustainable consumption. Sustainability 2019, 11, 6408. [CrossRef]

34. Rogala, A. Zainteresowanie żywnością lokalną wśród polskich konsumentów na tle polityki rolnej Unii Europejskiej. Handel Wewnętrzny 2015, 3, 227-238.

35. Minta, S. Bariery rozwoju rynku produktów regionalnych i tradycyjnych na przykładzie Dolnego Śląska. Rocz. Nauk. Stowarzyszenia Ekon. Rol. Agrobiznesu 2013, 15, 280-284.

36. Granvik, M.; Joosse, S.; Hunt, A.; Hallberg, I. Confusion and misunderstanding-Interpretations and definitions of local food. Sustainability 2017, 9, 1981. [CrossRef]

37. Sautet, F. Local and systemic entrepreneurship: Solving the puzzle of entrepreneurship and economic development. Entrep. Theory Pract. 2013, 37, 387-402. [CrossRef]

38. European Commission. Commission Regulation (EC) No 364/2004 of 25 February 2004 Amending Regulation (EC) No 70/2001 as Regards the Extension of Its Scope To include aid for Research and Development; 32004R0364; Publications office of the European Union: Brussels, Belgium, 2004.

39. Edwards-Jones, G. Does eating local food reduce the environmental impact of food production and enhance consumer health? Proc. Nutr. Soc. 2018, 69, 582-591. [CrossRef]

40. Halldórsdóttir, P.Ó.; Nicholas, K.A. Local food in Iceland: Identifying behavioral barriers to increased production and consumption Local food in Iceland: Identifying behavioral barriers to increased production and consumption. Environ. Res. Lett. 2016, 11,1-12. [CrossRef]

41. Korhonen, K.; Kotavaara, O.; Muilu, T.; Rusanen, J. Accessibility of local food production to regional markets-case of berry production in Northern Ostrobothnia, Finland. Eur. Countrys. 2017, 9, 709-728. [CrossRef]

42. Maye, D.; Ilbery, B. Regional economies of local food production: Tracing food chain links between "specialist" producers and intermediaries in the Scottish-English borders. Eur. Urban Reg. Stud. 2006, 13, 337-354. [CrossRef]

43. Romero-López, A.R.; Ramos, F.M. Understanding the linkages between small-scale producers and consumers through the analysis of short food supply chains in a local market in Nopala de villagrán, Hidalgo, Mexico. Cuad. Desarro. Rural 2017, 14, 52-67. [CrossRef]

44. Ballantyne-Brodie, E.; Telalbasic, I. Through service design strategies designing local food systems in everyday life through service design strategies. Des. J. 2017, 20, 3079-3095.

45. Benedek, Z.; Balázs, B. Current status and future prospect of local food production in Hungary: A spatial analysis. Eur. Plan. Stud. 2016, 24, 607-624. [CrossRef]

46. Lake, D.; Sisson, L.; Jaskiewicz, L. Local food innovation in a world of wicked problems: The pitfalls and the potential. J. Agric. Food Syst. Community Dev. 2015, 5, 13-26. [CrossRef]

47. Lutz, J.; Smetschka, B.; Grima, N. Farmer Cooperation as a Means for Creating Local Food Systems-Potentials and Challenges. Sustainability 2017, 9, 925. [CrossRef]

48. Martinez, S.W. Policies Supporting Local Food in the United States. Agriculture 2016, 6, 43. [CrossRef]

49. Papaoikonomou, E.; Ginieis, M. The relationship between producers and consumers in local food systems: Analysis of their practices and narratives. Rev. Int. Organ. 2015, 2015, 101-122.

50. Perrett, A.; Jackson, C. Local food, food democracy, and food hubs. J. Agric. Food Syst. Community Dev. 2015, 6, 7-18. [CrossRef]

51. Sanz-Cañada, J.; Muchnik, J. Geographies of origin and proximity: Approaches to local agro-food systems. Cult. Hist. Digit. J. 2016, 5, 1-19. [CrossRef]

52. Willis, D.B.; Carpio, C.E.; Boys, K.A. Supporting local food system development through food price premium donations: A policy proposal. J. Agric. Appl. Econ. 2016, 48, 192-217. [CrossRef]

53. Albrecht, C.; Smithers, J. Reconnecting through local food initiatives? Purpose, practice and conceptions of value. Agric. Hum. Values 2018, 35, 67-81. [CrossRef]

54. Crespo, J.; Requier-Desjardins, D.; Vicente, J. Sciences Politiques Toulouse-Why can collective action fail in Local Agri-food Systems? A social network analysis of cheese producers in Aculco, Mexico. Food Policy 2014, 46, 165-177. [CrossRef]

55. Ferrazzi, G.; Ventura, V.; Ratti, S.; Balzaretti, C. Consumers' preferences for amlocal food product: The case of a new Carnaroli rice product in Lombardy. Ital. J. Food Saf. 2017, 6, 71-74. 
56. Lim, K.H.; Hu, W. How local is local? A reflection on canadian local food labeling policy from consumer preference. Can. J. Agric. Econ. 2016, 64, 71-88. [CrossRef]

57. Rytkönen, P.; Bonow, M.; Girard, C.; Tunón, H. Bringing the consumer back in-The motives, perceptions, and values behind consumers and rural tourists' Decision to buy local and localized artisan food-A Swedish example. Agriculture 2018, 8, 58. [CrossRef]

58. Wenzig, J.; Gruchmann, T. Consumer preferences for local food: Testing an extended norm taxonomy. Sustainability 2018, 10, 1313. [CrossRef]

59. Schmit, T.M.; Jablonski, B.B.R.; Mansury, Y. Assessing the economic impacts of local food system producers by scale: A case study from New York. Econ. Dev. Q. 2016, 30, 316-328. [CrossRef]

60. Selfa, T.; Qazi, J. Place, taste, or face-to-face? Understanding producer-consumer networks in " local" food systems in Washington State. Agric. Hum. Values 2005, 22, 451-464. [CrossRef]

61. Soares, P.; Martínez-Mián, M.A.; Caballero, P.; Vives-Cases, C.; Carmen, M. Alimentos de producción local en los comedores escolares de Espana. Gac. Sanit. 2017, 31, 466-471. [CrossRef]

62. Burke, T.K.; Durr, C.; Reamer, D. The importance of local foods to users of food pantries in accessible rural AlaskaNo Title. J. Agric. Food Syst. Community Dev. 2018, 8, 53-69.

63. Forné, F.F. El turisme gastronòmic: Autenticitat i desenvolupament local en zones rurals. Doc. d'Anàlisi Geogràfica 2015, 61, 289-304. [CrossRef]

64. Madaleno, A.; Eusébio, C.; Varum, C. Purchase of local food products during trips by international visitors. Int. J. Tour. Res. 2018, 20, 115-125. [CrossRef]

65. Sengel, T.; Karagoz, A.; Cetin, G.; Dincer, F.I.; Ertugral, S.M.; Balik, M. Tourists' approach to local food. Procedia-Soc. Behav. Sci. 2015, 195, 429-437. [CrossRef]

66. Cobb, L.K.; Appel, L.J.; Franco, M.; Jones-Smith, J.C.; Nur, A.; Anderson, C.A.M. The Relationship of the local food environment with obesity: A systematic review of methods, study quality, and results. Obesity 2015, 23, 1331-1344. [CrossRef] [PubMed]

67. Gilliland, J.; Sadler, R.; Clark, A.; Connor, C.O.; Milczarek, M.; Doherty, S. Using a Smartphone application to promote healthy dietary behaviours and local food consumption. BioMed Res. Int. 2015, 2015, 1-11. [CrossRef] [PubMed]

68. Morland, K.B.; Evenson, K.R. Obesity prevalence and the local food environment. Health Place 2016, 15, 491-495. [CrossRef] [PubMed]

69. Murphy, M.; Badland, H.; Mohammad, J.K.; Astell-Burt, T.; Trapp, G.; Villanueva, K.; Mavoa, S.; Davern, M.; Giles-Corti, B. Indicators of a health-promoting local food environment: A conceptual framework to inform urban planning policy and practice. Health Promot. J. Aust. 2017, 28, 82-84. [CrossRef] [PubMed]

70. Pelletier, J.E.; Laska, M.N.; Neumark-Sztainer, D.; Story, M. Positive attitudes toward organic, local, and sustainable foods are associated with higher dietary quality among young adults. J. Acad. Nutr. Diet. 2013, 113, 127-132. [CrossRef] [PubMed]

71. Perline, A.; Heuscher, A.; Sondag, A.; Brown, B. Perceptions of local hospitals and food producers on opportunities for and barriers to implementing farm-to-hospital programs. J. Agric. Food Syst. Community Dev. 2015, 6, 147-160. [CrossRef]

72. Litavniece, L.; Silicka, I.; Dembovska, I.; Tretjakova, R. The significance of local food in the consumption of modern consumer. In Proceedings of the Foodbalt, Jelgava, Latvia, 27-28 April 2017; pp. 189-194.

73. Golubetskaya, N.; Kosheleva, T.; Kunin, V. Problems of innovative development of an entrepreneurship in the industry in the conditions of upgrade of Economy. In Proceedings of the IOP Conference Series: Earth and Environmental Science; Institute of Physics Publishing: Bristol, UK, 2017; p. 1.

74. Wyrzykowska, B. Przedsiębiorczość intelektualna jako kompetencja współczesnego menedżera. Zesz. Nauk. Szk. Głównej Gospod. Wiej. Warszawie 2012, 100, 32-33.

75. Hausner, J.; Laurisz, N.; Mazur, S. Przedsiębiorstwo społeczne-konceptualizacja. Ekon. Społeczna Teksty 2006, $2,3$.

76. Huczek, M. Przedsiębiorczość ekologiczna a rozwój lokalny. Przedsiębiorczość-Eduk 2010, 6, 271-279.

77. Kurowska, M.; Matejun, M.; Szymańska, K. Zewnętrzne uwarunkowania rozwoju przedsiębiorczości technologicznej. In Przedsiębiorczość Technologiczna w Małych i Średnich Firmach. Czynniki Rozwoju; Lachiewicz, S., Matejun, M., Walecka, A., Eds.; Wydawnictwo WNT: Warszawa, Poland, 2013; pp. 49-53.

78. Nowacka, U. Kreowanie przedsiębiorczości intelektualnej. Pr. Nauk. Jana Dtugosza Częstochowie 2011, 5, 159-172. 
79. Piekut, M. Innowacyjna przedsiębiorczość szansą rozwoju sektora MSP. Ekon. Organ. Gospod. Żywnościowej Zesz. Nauk. SGGW 2010, 86, 41-54.

80. Polowczyk, Ł.P. Społeczna odpowiedzialność biznesu a biznes społeczny. Zarzadzanie Zmianami Zesz. Nauk. 2013, 1, 6 .

81. Sobecki, R.; Kargul, A.; Kochanowska, J. Przedsiębiorstwo rodzinne-definicje i stan wiedzy. In Przedsiębiorstwo Rodzinne w Gospodarce Globalnej; Sobecki, R., Ed.; Szkoła Główna Handlowa w Warszawie-Oficyna Wydawnicza: Warszawa, Poland, 2014; pp. 13-36. ISBN 9788373789111.

82. Wielki, J.; Sytnik, I.; Sytnik, B. Biznes internetowy jako czynnik rozwoju przedsiębiorczości regionalnej: Współczesne modele i tendencje. Barom. Reg. 2017, 15, 32.

83. Mars, M.M.; Schau, H.J. What is local food entrepreneurship? Variations in the commercially and socially oriented features of entrepreneurship in the southeastern Arizona local food system. Rural Sociol. 2017, 83, 568-597. [CrossRef]

84. Przedsiębiorczość i Zarządzanie w Małej i Średniej Firmie: Teoria i Praktyka; Lisowska, R.; Ropega, J. (Eds.) Wydawnictwo Uniwersytetu Łódzkiego: Łódź, Poland, 2016; ISBN 9788380881341.

85. Szczepaniak, I. Czynniki i uwarunkowania rozwoju małych i średnich przedsiębiorstw w warunkach gospodarki opartej na wiedzy. Nierówności Społeczne a Wzrost Gospod. 2007, 10, 573-583.

86. Morris, M.; Lewis, P. The determinants of entrepreneurial activity: Implications for marketing. Eur. J. Mark. 1995, 29, 31-48. [CrossRef]

87. Backman, M.; Karlsson, C. Determinants of entrepreneurship. Is it all about the individual or the region? CESIS Electron. Work. Pap. Ser. 2013, 338, 2-24.

88. Young, C.; Karpyn, A.; Uy, N.; Wich, K.; Glyn, J. Farmers' markets in low income communities: Impact of community environment, food programs and public policy. Community Dev. 2011, 42, 208-220. [CrossRef]

89. Schmit, T.M.; Jablonski, B.B.R.; Laughton, C. Comparing farm financial performance across local foods market channels. J. Ext. 2019, 57. Available online: https://joe.cfaes.ohio-state.edu/joe/2019april/rb6.php (accessed on 27 August 2019).

90. Earle, M.D. Innovation in the food industry. Trends Food Sci. Technol. 1997, 8, 166-175. [CrossRef]

91. Moellers, J.; Birhala, B. Community supported agriculture: A promising pathway for small family farms in Eastern Europe? A case study from Romania. (Special Issue: Rural areas in transition.). Landbauforsch. Volkenrode 2014, 64, 139-150.

92. Jablonski, B.B.R.; Sullins, M.; McFadden, D.T. Community-supported agriculture marketing performance: Results from pilot market channel assessments in Colorado. Sustainability 2019, 11, 2950. [CrossRef]

93. Boys, K.A.; Fraser, A.M. Linking small fruit and vegetable farmers and institutional foodservice operations: Marketing challenges and considerations. Renew. Agric. Food Syst. 2019, 34, 226-238. [CrossRef]

94. Kallas, Z.; Alba, M.F.; Casellas, K.; Berges, M.; Degreef, G.; Gil, J.M. The Development of Short Food Supply Chain for Locally Produced Honey: Understanding Consumers' Opinions and Willingness to Pay in Argentina. Available online: https://ideas.repec.org/p/nmp/nuland/2849.html (accessed on 20 December 2019).

95. Engelseth, P. Reasons for adapting information connectivity in the short supply chains of local food producers. In Driving Agribusiness with Technology Innovations; IGI Global: Hershey, PA, USA, 2017; pp. 107-124. ISBN 9781522521082.

96. Cho, E.; Lee, J.O. Local food stores as a platform strategy: A case of Wanju local food station. Information 2015, 18, 195-202.

97. Abatekassa, G.; Peterson, H.C. Market access for local food through the conventional food supply chain. Int. Food Agribus. Manag. Rev. 2011, 14, 63-82.

98. Haythorn, C.M.; Knudsen, D.C.; Farmer, J.R.; Antreasian, C.C.; Betz, M.E. It's all in the SKU: Getting food from somewhere from the field to the dinner plate while using a large scale retailer. Sustainability 2019, 11, 892. [CrossRef]

99. Givens, G.; Dunning, R. Distributor intermediation in the farm to food service value chain. Renew. Agric. Food Syst. 2019, 34, 268-270. [CrossRef]

100. Ljungberg, D.; Jüriado, R.; Gebresenbet, G. Conceptual Model for Improving Local Food Supply Chain Logistics. In Proceedings of the 13th WCTR, Rio de Janeiro, Brazil, 15-18 July 2013; pp. 1-18.

101. Bosona, T.; Nordmark, I.; Gebresenbet, G.; Ljungberg, D. GIS-Based Analysis of Integrated Food Distribution Network in Local Food Supply Chain. Int. J. Bus. Manag. 2013, 8, 13. [CrossRef] 
102. Ainley, S.; Kline, C. Moving beyond positivism: Reflexive collaboration in understanding agritourism across North American boundaries. Curr. Issues Tour. 2014, 17, 404-413. [CrossRef]

103. Hardesty, S.D.; Leff, P. Determining marketing costs and returns in alternative marketing channels. Renew. Agric. Food Syst. 2010, 25, 24-34. [CrossRef]

104. Bauman, A.; Thilmany, D.; Jablonski, B.B.R. Evaluating scale and technical efficiency among farms and ranches with a local market orientation. Renew. Agric. Food Syst. 2019, 34, 198-206. [CrossRef]

105. Deller, S.C.; Lamie, D.; Stickel, M. Local foods systems and community economic development. Community Dev. 2017, 48, 612-638. [CrossRef]

106. Malak-Rawlikowska, A.; Majewski, E.; Was, A.; Borgen, S.O.; Csillag, P.; Donati, M.; Freeman, R.; Hoàng, V.; Lecoeur, J.L.; Mancini, M.C.; et al. Measuring the economic, environmental, and social sustainability of short food supply chains. Sustainability 2019, 11, 4004. [CrossRef]

107. Bazzani, C.; Canavari, M. Alternative agri-food networks and short food supply chains: A review of the literature. Econ. Agro Aliment. 2013, 15, 11-34. [CrossRef]

108. Charatsari, C.; Kitsios, F.; Lioutas, E.D. Short food supply chains: The link between participation and farmers' competencies. Renew. Agric. Food Syst. 2019, 2019, 1-10. [CrossRef]

(C) 2020 by the authors. Licensee MDPI, Basel, Switzerland. This article is an open access article distributed under the terms and conditions of the Creative Commons Attribution (CC BY) license (http://creativecommons.org/licenses/by/4.0/). 